\title{
Contesting history and identity formation in Paul and in South Africa
}

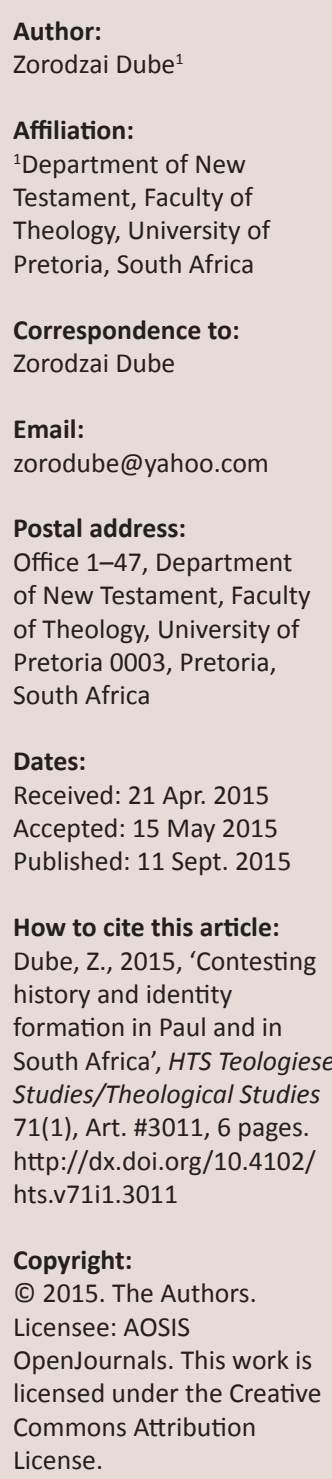

This study compares dynamics in the contestation of history and identity between Paul to post-1994 white Afrikaners in South Africa. In reference to Paul, I am interested in how the followers of the nascent Hellenistic Gentile Christian movement claimed legitimacy as the true Jews, usurping the monopoly of the identity 'true Jews' from the Jews, who believed that they alone, stand to claim the Abrahamic promise. Instead, Paul contested the Jewish history and identity, claiming that his Gentile Christians were, in fact, the true Jews - how so? The analysis shall be juxtaposed, providing a discursive analysis to the Afrikaners, who regularly receive claims that they do not belong to South Africa. Specifically, I look into how they contest the South African oral history, claiming that in fact, they are legitimate and the original inhabitants. The study notes that in both cases, identity is constructed through the contestation of history and identity. Thus, the comparison shall be narrowed down to how history is variably, contested for identity formation. Though living within the same locale, the different social groups interpret history differently and variously, appeal to different conspicuous figures and events as their identity markers.

\section{Introduction}

History is contested not from facts, but from how it is ideologically interpreted - its discourse. When I mention 'not from facts', I mean that there is no objective history, rather the subjective recollections based on identities - its historiography. This study, initially, developed from conversations with my Afrikaner colleagues over a glass of wine in Pretoria East, South Africa. ${ }^{1}$ Being a foreigner originally from Zimbabwe, at first I did not understand that in South Africa different ethnic groups have a different construction of the oral past, which feeds into the manner in which they construct their subjective identities. These initial casual conversations made me think - analogically - how Paul contested the Jewish history, thereby proclaiming to his Gentile Hellenistic Christian community to be the true Jews. The second, important aspect that emerges from my study is the insight that social history constantly weaves our collective identity by revisiting and recrafting the past. This brings me to the third aspect, which is, our identities are anchored by what I may call, 'myths of existence'. Myths of existence, not because the narratives are false, but more in the sense of Benedict Anderson (1983:7), to imagine communities; that is, we construct our identities by constantly reimagining our past. The term 'reimaging' captures the idea that the past is not stable, but crafted through nationalistic sentiment as real - one to die for. The question is, how is the past contested to create identity, how is it (the past) collectively imagined as real - evoked passionately with tenacity and nationalistic feelings, as if it is there for the taking? With regard to Paul, how did he contest the Jewish history to place his nascent Christian movement as the legitimate heir - the true Israel? The same question can be asked of the South African Afrikaners: how do they contest history to legitimise their identity claiming: 'We are the true and original inhabitancy of this country.'

\section{Theory: Construction of history and identity formation}

In social memory studies, Maurice Halbwachs (1980:12), a student of Emile Durkheim, notes that 'social frameworks' influence the various ways in which our memory is retold (Kirk 2005:1). Simply put, social frameworks are the collective experiences of a particular people (Halbwachs 1980:38). The basic assumption here is that, people groups share particular experiences and when confronted with new experiences, the past acts like a memory bank that influences how we must proceed. With regard to memory, Halbwachs (1980:54) acknowledges that experiences are arranged in terms of importance, meaning that certain memories stand out more visibly than the others and are easily remembered as a characteristic to a group. 1.The discussion took place on the 14 January 2015, at Atterbury Value Mart, Spar Ribs restaurant. The discussion was tape recorded
and transcribed for analysis. The surnames of the participants are: Geldenhuis, De Bruin and Van Vuuren. Only the surnames shall be provided as per agreement with the participants. 
Thus, to remember the past is an active interpretative process in which a part of the past is placed at the service of present needs - the past is subjectively retold in the present for identity formation (Schwartz 2005:43). Memory provides meaning. But, we do not remember all of the past every day, which provokes the important question - how is the past selected and interpreted? Alan Kirk (2005:1) suggests that in remembering, all we do is to 'key' or frame the present in view of the past, providing the present with a sense of meaning, continuity and stability. Simply, the present provides the content concerning how the past must be remembered, while the past provides the meaning frame to the present (2005:4). In remembering we 'key or frame' new experiences making them meaningful to the community (2005:10). Thus, memory works dynamically by reappropriating the past in moulding, reimaging and stabilising group identity (Bhabha 2005:123; Kelber 2005:226).

Burton Mack (1988:66) suggests that the early church's social circumstances generated the memory of Jesus, in that the past was not uniformly remembered, nor was its meaning stable and consistent. Instead, the collective needs of the early church provided the memory content concerning how Jesus was remembered. Before investigating how the past was remembered and contested vis-à-vis the Jews, a brief review of studies that have a controlling influence over the matter, is necessary.

\section{Recent discussions on Jewish- Gentile identification}

During and soon after the death of Jesus (c. 30 CE), the Jesus followers continued to identify themselves as Jews and perhaps merely regarded themselves as an internal reform movement within Judaism (Esler 1998:i). It seems identity friction arose when the nascent Christian movement began to bring more Gentiles to fellowship with less cultural sensitivity. The conflict over table fellowship in Galatians $2 \mathrm{ff}$. seems to provide a snapshot concerning the growing identity conflict between the Jews and the Gentile Hellenistic Jews. Hellenistic Jews were Jews who had resided in the diaspora, especially in Greek cities across the empire and had adopted a common lifestyle in these cities (Esler 1998:i). These are known to have built synagogues across the empire and continued to celebrate their Jewish identity. However, in terms of identity, Jerusalem Jews regarded their diaspora cousins with suspicion. When Paul converted a number of Gentiles to faith, it meant that the Gentiles had to be equally accepted to fellowship, which created cultural and identity conflict. It seems, when Paul referred to the 'new Israel', he was referring to the emergence of the Gentile Hellenistic Christian group, whose identity and history was less based on the law and their ties to Jerusalem, than on their faith in Jesus. Paul's theology seems to carve a new identity, one that seeks to find continuity with the Jewish history, yet equally acknowledging the unique identity of his diasporic, cosmopolitan and heterogeneous group (Kamudzandu 2010:87).

According to E.P. Sanders (1977:xxix) and James Dunn (2005), proponents of the recent dominant paradigm dubbed the 'new perspectives on Paul' which utilises sociological insights, say that the contention between the Jews and the Gentiles emanated from the refusal of the Jews - because of their strong belief in the idea of election and predestination to open their social boundaries to accommodate the Gentiles. They believed that the Jews are a divinely elected social group, whose existence is guaranteed by their unique social position, which is ascertained by keeping the Jews' laws - covenantal nomism. James Dunn (2005:110) expanded the initial ideas of Sanders (1977) to argue that keeping the Jewish law, was intrinsically intertwined with Jewish identity formation. The observance of the Torah (circumcision, Sabbath, purity and dietary laws) ensured social boundary markers that excluded non-Jews.

\section{Contesting history, memory and identification}

Arguably, the recent and current discussions concerning Jewish-Gentile relations have not discussed the contestation of history as a process of identity formation, instead the focus, as evidenced by the writings of James Dunn (2005) and E.P. Sanders (1977), has been on intergroup ethnic dynamics between the Jews and the Gentiles. I argue that, taking memory as the main analytical variable that would shift the focus from intergroup dynamics to understanding how history was, variably, evoked and reinterpreted for identification.

In contesting history, Paul categorically states: 'For we are the circumcision, who worship by the Spirit of God and glory in Christ Jesus and put no confidence in the flesh' (Phlp 3:3). Importantly, the above verse can be regarded as summing up how Paul was contesting the Jewish history and in the process bolstering the identity of his community. The verse has three parts:

1. 'For we are the circumcision': This is clearly an identity marker in which Paul is saying his Hellenistic Gentile Christians are the true Jews. Thus, Paul appears to be contrasting and contesting the history and identity 'true $\mathrm{Jew}^{\prime}$, as it was commonly known. Being a Jew in a proper sense was defined by blood or ancestry, that is, a person was supposed to be able to trace one's bloodline to David and Abraham. The law was seen as the overt ethical identity marker. In contrast, Paul replaces the bloodline and the laws with the spirit and traces the identity of his community, not from Moses but to Jesus. In the process, Paul accuses the Jews for not understanding the meaning of 'circumcision', arguing that in its originally intent, circumcision was supposed to be a spiritual marker which identifies the Jews as God's people. Thus, for Paul, the internal spiritual marker takes precedence over the overt external mark of circumcision. In this regard, the Gentiles who now receive the Abrahamic promise by faith, are equally and legitimate Jews and heirs to the promise, by faith.

2. The second part of the verse further describes the identity of the new Israel (Gentile-Hellenistic Christians), saying, 
'who worship by the Spirit of God and glory in Christ Jesus.' In Romans 3, Paul emphasised, saying:

No, a person is a Jew who is one inwardly; and circumcision is circumcision of the heart, by the Spirit, not by the written code. Such a person's praise is not from other people, but from God. (v. 29)

Paul's argument for a spiritual Israel is clearly expressed in Romans 9:6, where he says: 'It is not as though God's word had failed. For not all who are descended from Israel are Israel.' Paul cancels claims to identity based on blood, thus instead he claimed that true Israel is through the spirit, he internalised ethnicity.

3. Lastly, Paul says: 'Put no confidence in the flesh.' Paul's notion of a spiritual Israel received more attention when he addressed the Galatians (6:13), saying: 'Not even those who are circumcised keep the law, yet they want you to be circumcised that they may boast about your circumcision in the flesh.' He disregarded the Jewish identity based on the law and circumcision, saying: 'For neither is circumcision anything, nor uncircumcision, but a new creation' (Gl 6:15). Seemingly, Paul is arguing that both the Jews and the Gentiles should transcend their present ethnic confirms, to aspire to a high identity, which is a new creation. Aspiring to a new identity of 'new creation' puts both the Jews and the Gentiles at a similar level they all need to transform from their current identities to embrace the true and the new identity based on Jesus.

Clearly, Paul is contesting the Jewish history and the identity 'Jew'; by spiritualising and internalising it to fit the diasporic and heterogeneity nature of his Gentile Hellenistic community (Carter 2004:17). To do this, Paul does not claim identity from Moses and the Law, instead he constructs the identity of the Gentile Christians, tracing it to Abraham and Jesus, thus making the Law and Moses a diversion from God's initial idea of a spiritual community. Thus for Paul which he argues to be the true genealogy - true Israel are those who obey spiritually in their heart; they keep the law of God in their hearts and do not focus on the inscriptions on the stones and bodily markers.

The point is not facts or truth, but rather, the discourse around which narratives are presented. I mean, when Paul claims that true Israel are those who are spiritually marked, based on Abraham and Jesus and that the Law and ancestry must not be taken as identity markers, he is contesting how the Jews interpreted their history and identity. Thus, to dispute Paul's historiography is to miss the point which is, identity is not created from facts, but rather, from 'keying' the present to the past figures and narratives, making the past subject to the reconstructions. It is commonly accepted that Paul narrates and interprets salvation events in a particular way, 'he himself writes history and constructs a new religious world' (Schnelle 2003:32). Importantly, there are interesting issues that Paul raises in reconstructing the identity of the 'new community' - the Gentile Hellenistic Christians. Firstly, Paul is selective with regard to which ancestors to build upon for his argument. Paul avoids narratives that suggest Jewish exclusivity, for example, the Moses narratives which give the impression of an exclusive group based on keeping the Law, which if further pursued would be detrimental to his argument. Instead, Paul is comfortable in referring back to Abraham, seeing Abraham's calling as a narrative of faith, that is, one who obeyed by faith 400 years before the Torah (Rm 4ff.). Later, I shall look at how the Afrikaans people prefer to appeal to selective ancestors and the importance of such individuals to their process of identity formation. Secondly, in contesting history, Paul disputes physical marks such as circumcision, and instead claims that circumcision was internal. Later, I shall look at how the Afrikaans people argue for the 'concept of empty land' to contest the idea of original inhabitancy in South Africa. Thirdly, in contesting history, Paul argues that true Israelites are not defined by their blood, but by their spiritual obedience, thus, shifting historiography from ethnicity to morality. Later, I juxtapose this notion with how the Afrikaners claim that being African is not by blood or skin colour but by shared African values, thus abolishing historiographies that sustain identities based on race.

\section{Contestation of history and identity in South Africa}

I found the manner in which Paul discursively claimed the identity of his Gentile Christian communities illuminating; one that provides interesting analogies to how identities are constructed through contestation of history in South Africa. South Africa has more than two ethnicities, but historically contention mostly arises, when the majority black South African people refer to their white neighbours, whom they occasionally label as foreigners - a labelling which the white Afrikaners believe is very unfortunate. The debate did not start now; it is as old as when the two groups met. I observed parallels and analogies in the way history is reinterpreted in the current identity context in South Africa - with specific reference to the Afrikaners - to the discussion above about Paul and the emerging Gentile Christian community during the 1st century CE. Specifically and arguably, the way Paul argued and contested the Jewish history and identity, echoes parallel patterns to how the Afrikaners contest history to redefine their identity. Again, the merits of the analogy and the comparison must not be verified from a historical trajectory, but from how narratives create imagined communities; our collective identity, which we are passionately ready to defend.

My discussion was with three Afrikaner men (Mr Geldenhuis, Mr Van Vuuren, and Mr De Bruin), who, in my analysis seem to represent a larger constituency with their views. In conversation with Mr Geldenhuis, he vehemently states that Afrikaner people are, equally, the original inhabitants of South Africa, because of what I shall label as the 'empty land myth' (Marks 2012). ${ }^{2}$ I see his argument as being similar to

2.The Mail \& Guardian (Marks 2012) contains an article which argues that: ' $[T]$ he apartheid-era propaganda asserted that by a quite remarkable coincidence the present-day African inhabitants of South Africa crossed its northern frontier, the Limpopo River, very conveniently at more or less the same moment as the first European settlers landed at its southern tip, the Cape of Good Hope, in the midEuropean settlers landed at its southern tip, the Cape of Good Hope, in the
1600 s. They were therefore purported to be as recent in arrival as the whites.' 
that of Paul, who disputed the merits of a Jewish identity based on circumcision, in that, Mr Geldenhuis's contestation disputes claims that there are physical geographic marks that defined South Africa. In fact, there were no geographic boundaries during the 1600s. Geldenhuis, patriotically believes in his contestation of history, that there was no South Africa (as a country) when the Boers arrived and settled in the Cape. Instead, as he claims, if the black people existed, they were nomadic, following the directions of their particular chiefs. Like Paul, who denies circumcision, $\mathrm{Mr}$ Geldenhuis denies claims to identity based on geography or any physical markings. Nullifying circumcision must have been preposterous to the Jews. Equally, to a majority of black South African people, to claim that the land was empty is preposterous.

What is important to this study, is not the veracity of oral or written history about the claims, but rather how history is contested for identification - its discourse. Like Paul, who denied physical marks as identity markers, Mr Geldenhuis contests physical geography as basis of identity. If circumcision was not the identity marker to Paul this meant, being a Jew had another connotation - spiritual identity. Similarly, to Mr Geldenhuis, if the land was empty, South Africans are defined, not by physically boundaries but by other means. Why does Mr Geldenhuis want to define their identity around the 'empty land myth'? From a theological point of view, it evokes the biblical narratives about Abraham and Moses, thus seeing South Africa as a God-given land. Religious myths have a tendency to ratchet identity construction from ordinary history to metaphysical territory 'God gave us the land'. By theologising and mystifying identity, Mr Geldenhuis is able to accentuate his emotional attachment to the land of South Africa, as something to die for. Mr Geldenhuis was able to contest history and identity from two fronts -claiming that the land was empty and that God preordained the occupation, and by so doing, secondly, he disputes other histories and claims to land. Indeed, he is a true South African.

Importantly, Geldenhuis's friend, Mr Van Vuuren says South Africa is for everyone, thus removing physical identity markers instead, arguing from a metaphysical point of view similar to saying 'I am South African because I love South Africa'. Mr Van Vuuren's argument overlaps with that of Paul who, in contesting history and identity internalised the identity of his imagined community. As Paul says, the real Jews are not those with physical marks, but those who, inwardly and spiritually follow God. Mr Van Vuuren's basic argument is that, those who love the country need no documentation instead, they show it through their characterthey do not steal, commit murder and they respect the laws of the country. When Mr Van Vuuren was speaking, I was reminded of Paul, who makes almost a similar statement, in Romans 9:6, 'For not all who are descended from Israel are Israel.' Similarly, by listening to Mr Van Vuuren, one can say that not all South Africans are indeed South African that is, if they vandalise property and commit all kinds of crime. Through their deeds they make South Africa not to be South Africa, as much as Paul would say, when you are sinning, though one is circumcised, the mark of circumcision is invalidated. Noticeable, both Mr Van Vuuren and Paul, internalised identity. Like Paul, Mr Van Vuuren lists the nationalistic moral conducts of being a good neighbour or citizen, which to Paul, would come out as the fruits of the Spirit' $($ Gl 5, 6).

For a moment, I thought that Mr Van Vuuren wanted me a foreigner, to feel accommodated, which I did. Internally, I felt, though a Zimbabwean, I pay tax, I am a morally upright, peace-loving person - thus looking around the restaurant for a moment, I felt that I was a better South African through my deeds - morally a better South African than some who claim their identity based on their nationality. Importantly to this study, Mr Van Vuuren disputed nationality based on ethnicity, shifting it to morality. As Paul says in Galatians (6:13): 'Not even those who are circumcised keep the law, yet they want you to be circumcised that they may boast about your circumcision in the flesh'. If Paul were to speak today to South Africa he would say, 'South Africans want all foreigners to acquire identity documents, for one to be called a South African, instead, you are South Africans by heart'. Mr Van Vuuren made me think that like Paul, he is internalising identity, contesting identity based on ethnicity for something better. Like Paul who thinks of a 'new creation', there are people, like Mr Van Vuuren, who contest identity from a moral perspective. A moral or spiritual identity, to Paul is a 'new creation', gained by transcending current ethnic categories making Paul strive each day for moral perfection - 'Not that I have already obtained this or am already perfect, but I press on to make it my own, because Christ Jesus has made me his own' (Phlp 3:12). Clearly, it appears that Paul believed in the continuous moral improvement or perfection of humanity, which perhaps could be attributed to the influence of Stoic philosophy. Paul believed that better citizenship comes from internal regeneration based on the indwelling logos (Christ in me the hope of glory). Similarly, stoicism taught that a good person is one who is able to control his or her emotions such as anger, lust, fear and sexual impropriety (Seller 2006:108). A person endowed with the stoic logos, reacts with calm to life's vicissitudes, while those without the logos will visibly lack good judgement. Stoicism taught that, due to the indwelling logos, knowledge must translate into good deeds (Seller 2006:108). Hence, people with good virtue, transform their society through their good behaviour (Seller 2006:108). Because God is matter, those who share in the logos partake in the divine attributes; hence assume a superlative identity status inherently different from those without the logos. Important to this study is that, in contesting history and identity, both Paul and Mr Van Vuuren, believe in a new humanity that is attained from transcending our current degenerate ethnicities. The new being, as Paul would say, is the new and true Israel, and/or in the context of South Africa, a true South African is one who is morally responsible.

I also observed that my colleagues selectively build their identity and history from particular figures in the South 
African history. Contrary to my black friends, who when referring or talking in the context of their economic situations, are quick to remind me about liberation heroes such as Steve Biko and Thabo Mbeki, my white friends build their history and identity based on Nelson Mandela and Koos De la Rey. This is important - why these historical figures and not the rest? As we noted with Paul, who would go back to Abraham and not Moses, identity is contrasted around people and events that sympathise and identify with our experiences. To Paul, who wanted a less legalistic Christian movement, Abraham was the best ancestor to discursively craft an identity narrative for the emerging faith community.

To Mr De Bruin, Mandela symbolises unity and forgiveness. Mr De Bruin reveals that he loves his fellow black countrymen, but he is very afraid - a fear which stems from crime and fear of revenge. Like Abraham who symbolised inclusivity, Mandela represents an inclusive South Africa, one where people live in peace and tolerance. The feeling of fear expressed by Mr De Bruin makes him to restrict his identity around the other person in history - Koos De la Rey. I had heard about De la Rey from a colleague at work - Kobus Kok, but it was time to be schooled in history. General Koos De la Rey (1847-1914) was a Afrikaans military strategist during the Second Boer War. The Second Boer War represents the lowest morale index among the Afrikaner people from losing their superior identity to the British colonialists. But why would Mr De Bruin return to one of the lowest moments in history as his identity marker? His sense of insecurity makes him identify with Koos De la Rey in reviving nationalistic sentiments - 'we shall overcome'. Similarly, Du Plessis (2007) argues that post-1994 gave a sense of loss to the Afrikaner people, who feel that their history and pride has been taken away from them. Du Plessis argues that, among some Afrikaners, there is a call to revive their national pride, one which finds expression through songs by Bok van Blerk one of which says 'De la Rey, De la Rey, sal jy die Boere kom $l e i^{\prime}$, meaning De la Rey, De la Rey, will you come and lead the Boers. Du Plessis argues that the song is responding to sentiments against policies such as the 'black affirmative action', and 'black economic empowerment', which some Afrikaners see as deliberate sideling or reverse racism (Du Plessis 2007).

\section{Conclusion and remarks}

This study notes that identity is built from narratives, which regularly deploy or refer to history. However, history is not stable; it is no truth, instead, history is refashioned, recrafted to answer the present needs. History is remade by the needs of the present, thus deployed to sustain a particular conviction - a discourse.

With regard to Paul, the manner in which he compares Moses to Abraham was meant to develop an identity narrative that finds support from particular redeployment of the past. For example, mostly in Galatians, the Law and Moses are cast as impediment to grace. Importantly to this study, Paul is not emphasising grace for theological truth, but for ideological expediency - to make a point that his Hellenistic Christians are true heirs of the promise through faith, like Abraham. In Paul, history serves the present.

Whenever identities are constructed and defended, history is deployed. With regard to South Africa, my Afrikaner friends recast the past, contesting its interpretation to claim their identity. As they claim, in the 1600s, South Africa was an empty land - a claim that my black friends are ready to dispute. However, the important point is not whether the statement is true or false, but what identities it intends to build. If the land was empty, no single ethnicity can claim it as original inhabitancy. It therefore means, there are other identity categories that must be used. For example, South Africa is for all people, but not all are South Africans, some are less South African by not abiding by the laws of the country. Nonetheless, views articulated by Mr Geldenhuis, Mr Van Vuuren and Mr De Bruin represent each in their own way 'a mind-set shaped from the worldview shared by the beholder' (Loba-Mkole 2011:3). They indeed respond to views expressed by South Africans from other ethnic groups. Each group ultimately needs to take part in the reconstruction of the South African national identity in a spirit of dialogue and reconciliation.

From the study, therefore, the various versions of the past and collective identities are built from narratives, told as a consensus story, aiming to prop up our particular image our identity as a people. Equally, past figures make sense to us from a meta-narrative, in so far as they represent particular ideas inculcated by the community.

\section{Acknowledgements Competing interests}

The author declares that he has no financial or personal relationships which may have inappropriately influenced him in writing this article.

\section{References}

Anderson, B., 1983, Imagined communities, reflection on the origin and spread of Nationalism, Verso, London.

Bhabha, H., 2005, Location of culture, Routledge, Abingdon.

Carter, T.L., 2004, Paul and power of sin: Beyond the pale, Cambridge University Press, Cambridge.

Dunn, J., 2005, The new perspective on Paul, Mohr Siebeck, Tübingen.

Du Plessis, T., 2007, 'Song sparks questions of pride and prejudice', The Financial Mail Online, viewed 04 April 2015, from http://www.boerevryheid.co.za/forums/ archive/index.php/t-5456.html

Esler, P., 1998, Galatians, Routledge, London. http://dx.doi.org/10.4324/9780 203410769

Halbwachs, M., 1980, The collective memory, Harper \& Row, New York, NY.

Kamudzandu, I., 2010, Abraham as spiritual ancestor: A postcolonial Zimbabwean reading of Romans 4, Brill, Boston, MA. http://dx.doi.org/10.1163/ ej.9789004181649.i-265

Kelber, W., 2005, 'The works of memory: Christian origin as Mnemo history - A response', in A. Kirk \& T. Thatcher (eds.), Memory, tradition and text: Uses of the past in early Christianity, pp. 221-248, Society of Biblical Literature, Atlanta, GA. (Semeia Studies, 52).

Kirk, A., 2005, 'Social and cultural memory', in A. Kirk \& T. Thatcher (eds.), Memory, tradition and text: Uses of the past in early Christianity, pp. 1-24, Society of Biblical Literature, Atlanta, GA. (Semeia Studies, 52).

Loba-Mkole, J-C., 2011, 'Paul and Africa?', HTS Teologiese Studies/Theological Studies 67(1), 1-11. http://dx.doi.org/10.4102/hts.v67i1.888 
Mack, B.L., 1988, A myth of innocence: Mark and the Christian origins, Fortress Press, Philadelphia, PA.

Marks, S., 2012, 'SA ignorant about its land struggle', Mail \& Guardian, viewed 15 April 2015, from http://mg.co.za/article/2012-03-02-sa-ignorant-about-its-landstruggle/

Sanders, E.P., 1977, Paul and the Palestinian Judaism: A comparison of patterns of Religion, SPCK, London.
Schnelle, U., 2003, Apostle Paul: His life and theology, Baker Academic, Grand Rapids, MA.

Schwartz, B., 2005, 'Christian origins: Historical truth and social memory', in A. Kirk \& T. Thatcher (eds.), Memory, tradition and text: Uses of the past in early Christianity, pp. 43-56, Society of Biblical Literature, Atlanta, GA. (Semeia Studies, 52).

Seller, J., 2006, Stoicism, Acumen, Durham. 